\title{
Efecto específico a nivel agregado de la venta de alcohol en el índice de mortalidad por infarto de miocardio
}

\section{Aggregate level beverage specific effect of alcohol sale on myocardial infarction mortality rate}

| Yury EvgenY RAZVODOVSKY
Grodno State Medical University, Belarus

Enviar correspondencia a:

Grodno State Medical University, Belarus, str. Gorky 80, 230009,

tel.: + 37501527018 84, fax: +3750152435341.

E-mail: razvodovsky@tut.by

\section{RESUMEN}

Antecedentes: Las pronunciadas fluctuaciones en la mortalidad cardiovascular en los antiguos países de la Unión Soviética durante las últimas décadas han despertado enorme interés. Los indicios sugieren cada vez más que el modelo de "binge drinking" (ingesta compulsiva de alcohol) constituye un contribuidor potencialmente importante en el aumento de la tasa de mortalidad cardiovascular en las antiguas Repúblicas Soviéticas. Si aceptamos que un consumo excesivo ("heavy drinking") ocasional de bebidas de alta graduación aumenta el riesgo de mortalidad cardiovascular, entonces los paises donde este modelo constituye el modelo predominante deberian mostrar asociaciones positivas entre el consumo de licores y la mortalidad cardiovascular a nivel agregado. Propósito: Estimar el efecto especitico a nivel agregado de la venta de alcohol en la tasa de mortalidad por infarto de miocardio en culturas de la bebida que combinan un alto nivel per cápita de consumo de licores con modelos de beber explosivos. Método: se analizaron mediante análisis de series temporales ARIMA las tendencias en la venta especifica de alcohol per cápita y los indices de mortalidad por infarto de miocardio desde 1970 hasta 2005 en Bielorrusia. Resultados: Los resultados del análisis de las series temporales sugieren relaciones positivas entre las ventas de licores fuertes (vodka) per cápita y la tasa de mortalidad por infarto de miocardio. El análisis sugiere que el aumento de 1 litro en la venta de vodka per cápita resulta en un aumento de la tasa de mortalidad por infarto de miocardio del $7,2 \%$ (8,2\% de aumento en la mortalidad masculina y $6,8 \%$ en la femenina). Conclusiones: Los resultados del presente estudio sugieren una relación positiva entre las ventas de vodka y la tasa de mortalidad por infarto de miocardio a nivel agregado y apoyan la idea de que el "binge drinking" de licores fuertes constituye un factor de riesgo del infarto de miocardio a nivel individual. De esta manera, desde un punto de políticas públicas, el resultado de este estudio sugiere que los programas de prevención de la mortalidad relacionada con problemas cardiovasculares deberian estar más enfocados a tratar la estructura del consumo de alcohol.

Palabras clave: infarto de miocardio, venta de alcohol, análisis de series temporales ARIMA, Bielorrusia. recibido: mayo 2008

aceptadp: abril 2009

\section{ABSTRACT}

Background: The pronounced fluctuations in cardiovascular mortality in the countries of the former Soviet Union over the past decades have attracted considerable interest. The mounting evidence suggests that binge drinking pattern is a potentially important contributor to higher cardiovascular mortality rate in the former Soviet republics. There is assumption that if occasional heavy drinking of strong spirits increases the risk of cardiovascular mortality, countries where this is predominant drinking pattern should display positive association between spirits consumption and cardiovascular mortality at the aggregate level. Purpose: To estimate the aggregate level beverage specific effect of alcohol sale on myocardial infarction mortality rate in drinking culture, which combine a higher level of spirits consumption per capita with the explosive drinking pattern. Method: Trends in beverage specific alcohol sale per capita and myocardial infarction mortality rate from 1970 to 2005 in Belarus were analyzed employing ARIMA time series analysis. Results: The results of time series analysis suggest positive relation between strong spirits (vodka) sale per capita and myocardial infarction mortality rate. The analysis suggests that a 1 liter increase in vodka sale per capita would result in a $7.2 \%$ increase in myocardial infarction mortality rate (8.2\% increase in male mortality and $6.8 \%$ increase in female mortality). Conclusions: the results of the present study suggest a positive relation between vodka sale and myocardial infarction mortality rate at aggregate level and support the hypothesis that binge drinking of strong spirits is a risk factor of myocardial infarction at the individual level. Thus, from a public policy point of view, the outcome of this study suggests that cardiovascularrelated mortality prevention programs should put more focus on addressing alcohol consumption structure.

Key words: myocardial infarction, alcohol sale, ARIMA time series analysis, Belarus, 1970-2005. 


\section{INTRODUCCIÓN}

D urante la pasada década, las pronunciadas fluctuaciones en la mortalidad cardiovascular en los países que constituían la antigua Unión Soviética han despertado considerable interés (Britton y McKee, 2000; Chenet, McKee, Leon, Shkolnikov y Vassin, 2001). Hay evidencias indirectas de que estas fluctuaciones en la mortalidad pueden estar relacionadas con el consumo de alcohol (Razvodovsky, 2001, 2005; Nemtsov, 2002). Estas evidencias cuestionan la visión de una relación curvilinear entre el alcohol y la mortalidad cardiovascular que ha sido presentada reiteradamente en la literatura (Turnet y Anderson, 1990; Klatsky, Armstrong y Friedman, 1997; Corrao, Rubbiati, Bagnardi, Zambon y Poikolainen, 2000; Marmot, 2001; Anderson, 2005). Diversos estudios señalan las pautas de consumo como importantes contribuidores potenciales en una más alta tasa de mortalidad cardiovascular en las antiguas repúblicas Soviéticas (Britton y McKee, 2000; Chenet et al., 2001). El cambio de paradigma de volumen de bebida a modelo de ingesta (episodios de gran consumo compulsivo o "binge drinking" frente a un consumo regular y moderado) como primer determinante de mortalidad cardiovascular se apoya en crecientes muestras de las evidencias investigadas (Puddey, Rakic, Dimmitt y Beilin, 1999; Hemstrom, 2001; Mucamal, Conigrave, Mittleman, Camargo, Stampfer, Willet y Rimm, 2003; Room, Babor y Rehm, 2005). Los estudios que han analizado los modelos de ingesta han encontrado que el consumo episódico de grandes cantidades de alcohol puede precipitar la isquemia de miocardio y aumentar el riesgo de infarto de miocardio (Rossinen, Partanen, Koskinen, Toivonen, Kupari y Nieminen, 1996). Por ejemplo, en el proyecto MONICA, los hombres que habian consumido nueve o más bebidas cada día que bebían, comparados con aquellos que no habían bebido en absoluto, mostraban ratios extrañas de infarto de miocardio agudo de aproximadamente 2, incluso si sólo bebían uno o dos días por semana (Kuulasmaa, Tunstall-Pedoe, Dobson, Fortmann, Sans, Tolonen, Evans, Ferrario y Tuomilehto, 2000). En el Estudio Regional Británico de Corazón (BRHS), para aquellos hombres que consumian entre 3-6 bebidas por día durante los fines de semana, comparado con los hombres que consumían 1-2 bebidas diarias se daba un aumento del 20\% en el riego de infarto de miocardio (Sharper, Phillips, Pocock y Walker, 1987). En un estudio de control de casos se mostró que los hombres que bebían 9 o más bebidas alcohólicas por día durante 1-2 dias a la semana tenían aumento multiplicado del 2,4 del riesgo de padecer infarto de miocardio agudo, mientras que las mujeres que bebían 50 más bebidas por día mostraban un riesgo aumentado multiplicado por 2,8 (McElduff y Dobson, 1997). En el Estudio Kuopio sobre Riesgos de las Enfermedades de Corazón Isquémicas, los hombres cuya dosis regular de cerveza era de seis o más botellas por sesión tenían un aumento multiplicado por siete del riesgo relativo de un infarto de miocardio fatal (Kauhanen, kaplan, Goldberg y Salonen, 1997). En un estudio prospectivo de la población, el consumo cuantioso en hombres con un historial previo de infarto de miocardio se asociaba con un aumento significativo marginal del riego de muerte cardiovascular (Shaper y Wannamethee, 2000). Estos estudios sugieren que el "binge drinking" puede conducir a un aumento en la incidencia del infarto de miocardio mediante la provocación de espasmo arterial coronario o de isquemia de miocardio en aquellos que cuentan con enfermedades coronarias arteriales previas.

\section{INTRODUCTION}

T he pronounced fluctuations in cardiovascular mortality in the countries of the former Soviet Union over the past decades have attracted considerable interest (Britton \& McKee, 2000; Chenet, McKee, Leon, Shkolnikov \& Vassin, 2001). There is indirect evidence that these mortality fluctuations may be related to alcohol consumption (Razvodovsky, 2001, 2005; Nemtsov, 2002). This evidence challenged the view on a curvilinear relationship between alcohol and cardiovascular mortality that has been reported repeatedly in the literature (Turnet \&t Anderson, 1990; Klatsky, Armstrong \& Friedman, 1997; Corrao, Rubbiati, Bagnardi, Zambon \& Poikolainen, 2000; Marmot, 2001; Anderson, 2005). Several studies point to drinking pattern as a potentially important contributor to higher cardiovascular mortality rate in the former Soviet republics (Britton \& McKee, 2000; Chenet, et al., 2001). The change of the paradigm from drinking volume to drinking pattern (heavy episodic drinking or binge drinking versus regular moderate drinking) as the primary determinant of cardiovascular mortality is supported by mounting body of research evidence (Puddey, Rakic, Dimmitt \& Beilin, 1999; Hemstrom, 2001; Mucamal, Conigrave, Mittleman, Camargo, Stampfer, Willet \& Rimm, 2003; Room, Babor \& Rehm, 2005). Studies that have looked at pattern of drinking have found that episodic consumption of large amount of alcohol may precipitate myocardial ischemia and increased risk of myocardial infarction (Rossinen, Partanen, Koskinen, Toivonen, Kupari \& Nieminen, 1996). For example, in the MONICA project, men who consumed nine or more drinks per drinking day, as compared with those who did not drink at all, had odds ratio for acute myocardial infarction of approximately 2 even if they drank only one to two days per week (Kuulasmaa, Tunstall-Pedoe, Dobson, Fortmann, Sans, Tolonen, Evans, Ferrario \& Tuomilehto, 2000). In the British Regional Heat Study, for men who had 3-6 drink per day on weekends versus men, who had 1-2 drinks daily there was a $20 \%$ increase in the risk of myocardial infarction (Shaper, Phillips, Pocock \& Walker, 1987). In one case-control study it was shown that men, who drank 9 or more drinks per day on 1-2 days a week, had a 2,4-fold increase risk of acute myocardial infarction, while women who drank 5 or more drinks per day showed a 2,8-fold increase in risk (McElduff \& Dobson, 1997). In the Kuopio Ischemic Heart Disease Risk Study, men whose usual dose of beer was six or more bottles per session had a seven-fold increase in relative risk of fatal myocardial infarction (Kauhanen, Kaplan, Goldberg \& Salonen, 1997). In a population based prospective study heavy drinking in men with a history of previous myocardial infarction was associated with a marginally significant increase in risk of cardiovascular death (Shaper \& Wannamethee, 2000). These studies suggest that binge drinking may lead to an increase in incidence of myocardial infarction by either provoking coronary artery spasm or by the provocation myocardial ischemia in those preexisting coronary artery diseases. 
De hecho, un aspecto tan importante del consumo de alcohol como es la bebida de preferencia debería ser tomado en consideración para clarificar el rol de los modelos de consumo en las relaciones alcohol-cardiovasculares de mortalidad. Hay evidencias sugerentes que muestran que la elección de bebida alcohólica se asocia con el modelo de consumo. Por ejemplo, en Bielorrusia la mayoría de hombres y mujeres que practican el "binge drinking" consumen casi exclusivamente licores mientras que los poco bebedores y los moderados consumen una variedad mayor de bebidas (Razvodovsky, 2003). Sin embargo, se ha mostrado que un consumo de licores per cápita se relaciona positivamente con enfermedades de corazón en seis de nueve países occidentales (Brenner, 1987). De acuerdo con estos hallazgos, suponemos que si el consumo ocasional de licores fuertes aumenta el riesgo de infarto de miocardio, los países donde éste constituye el modelo de consumo predominante deberian mostrar una asociación positiva entre el consumo de licores y la mortalidad por infarto de miocardio a nivel agregado. En Bielorussia, el consumo ocasional de licores fuertes (vodka) y en grandes dosis constituye un modelo de consumo predominante (Razvodovsky, 2003). Por todo ello, podemos esperar una asociación a nivel agregado entre el consumo de vodka per cápita y la tasa de mortalidad por infarto de miocardio en este país. Para probar esta hipótesis, se analizaron las tendencias en las tasas de mortalidad por infarto de miocardio y las ventas de bebidas alcohólicas a nivel específico per cápita en Bielorrusia desde 1970 hasta 2005 aplicando análisis de series temporales.

\section{MATERIALES Y MÉTODOS}

Los datos sobre mortalidad por infarto de miocardio (tanto para el total de la población como los coeficientes por sexo) por cada 100.000 residentes y las ventas por bebida específica en litros de alcohol 100\% per cápita utilizados en este artículo se han extraído de los informes anuales, desde 1970 hasta 2005, del Ministerio de Estadística de Bielorrusia. Se da con frecuencia el caso de que, los cambios en las ventas per cápita de una bebida en concreto se correlacionan con la venta total de alcohol per cápita. Por consiguiente, para poder separar el efecto específico de las ventas de vodka per cápita del total de alcohol vendido se probó las ventas de vodka en cuanto a su ratio en el total de venta de alcohol. Los cambios en la dieta y en el consumo de cigarrillos son los factores más probables que pueden afectar la mortalidad por infarto de miocardio (Semenciw, Morrison, Mao, Johansen, Davies y Wigle, 1988). Por tanto, las ventas de cigarrillos per cápita se incluyeron como una variable independiente. Los cambios en la dieta no se presentan en este estudio porque se encontraron pocas evidencias de cambios rápidos en los modelos dietéticos entre los hombres y mujeres bielorrusos en las décadas de 1980 y 1990 que puedan tener una incidencia en fluctuaciones dramáticas de la tasa de mortalidad por infarto de miocardio. El análisis estadístico se llevó a cabo con el paquete STATISTICA 7. Se acepta comúnmente que las correlaciones bivariables entre dos series temporales basadas en datos sin elaborar son espurios debido a las fuentes comunes de tendencias y autocorrelaciones (Norstrom y Skog, 2001). Por tanto, para reducir el
In fact, such important aspect of drinking as beverage preference should be considered in order to clarify the role of drinking pattern in alcohol-cardiovascular mortality relations. There is suggestive evidence that alcoholic beverage preference is associated with drinking pattern. For example, in Belarus, binge drinking men and women almost exclusively spirits drinkers while light to moderate drinkers consumed a much wider variety of beverages (Razvodovsky, 2003). It has been shown, however, that consumption of spirits per capita is positive related to heart disease mortality in six of the nine Western countries (Brenner, 1987). In line with these findings, we assume that if occasional heavy drinking of strong spirits increases the risk of myocardial infarction, countries where this is predominant drinking pattern should display positive association between spirits consumption and myocardial infarction mortality at the aggregate level. In Belarus occasional consumption of strong spirits (vodka) in big doses is a predominant drinking pattern (Razvodovsky, 2003). This is good reason for the expectation a close aggregate-level association between vodka sale per capita and myocardial infarction mortality rate in this country. To test this hypothesis trends in myocardial infarction mortality rate and beverage-specific level of alcohol sale per capita in Belarus from 1970 to 2005 were analyzed applying time series analyses.

\section{MATERIAL AND METHODS}

The myocardial infarction mortality data (for the whole population and sex-specific coefficients) per 100.000 of residents and beverage-specific alcohol sales in litres of $100 \%$ alcohol per capita provided in the article is taken from the Ministry of Statistics of Belarus annual reports from 1970 to 2005. It is frequently the case that changes in per capita sale of one beverage will be correlated with total alcohol sale per capita. Therefore in order to separate the specific effect of vodka sale per capita from total alcohol sale we tested vodka sale in term of its ratio to total alcohol sale. Changes in diet and cigarette smoking are the most probable factors that may affect the myocardial infarction mortality (Semenciw, Morrison, Mao, Johansen, Davies \& Wigle, 1988). Therefore, sale of cigarette per capita were included as an independent variable. Data on change in dietary factors were not presented in this study because there is little evidence of rapid change in dietary pattern among Belarussian men and women in the 1980s and 1990s that has translated into the dramatic fluctuation in myocardial infarction mortality rate. The statistical analysis was conducted with the package STATISTICA 7. It is generally agreed that bivariate correlations between the two time-series based on raw data are spurious due to common sources of trends and autocorrelation (Norstrom \& Skog, 2001). Therefore in order to reduce the risk of obtaining a spurious relation between two variables that have common trends, the trends should be removed 
riesgo de obtener relaciones falsas entre dos variables con tendencias similares, las tendencias deben ser eliminadas mediante un procedimiento diferenciador: $\nabla x_{t}=x_{t}-x_{t-1}$ Esto significa analizar los cambios anuales en vez de los datos en bruto. El proceso de eliminar las variaciones sistemáticas entre series temporales, antes del examen de relaciones causales potenciales, se conoce como de "pre-blanqueado". Los residuos de una serie temporal estadísticamente adecuada se distribuyen como un proceso de ruido blanco. Un paso más nos permite la inspección de la función de correlaciones cruzadas para estimar la asociación entre las dos series temporales pre-blanqueadas. Esta técnica para emprender análisis de series temporales fue sugerida por Box y Jenkins y se la conoce a menudo como el modelo ARIMA (media móvil integrada autoregresiva) (Box y Jenkins, 1976). En este artículo, hemos usado este modelo para estimar la relación entre la tasa de mortalidad por infarto de miocardio en las series temporales y el nivel de ventas de una bebida específica de alcohol per cápita.

\section{RESULTADOS}

Las tendencias tanto en el total como por sexos de las tasas de mortalidad por infarto de miocardio y de las ventas de vodka per cápita se muestran en las Figuras 1-3. La evidencia gráfica sugiere que las tendencias tanto en la venta de vodka per cápita como en la mortalidad por infarto de miocardio para hombres y mujeres parecen seguirse unas a otras durante las series temporales. Las dos series temporales fluctúan durante dicho periodo para ambos sexos: disminuyen durante la primera mitad de la década de 1980, aumentan dramáticamente desde 1988 hasta 1993, donde la mortalidad masculina aumenta un 55,2\% (de 23,2 hasta 36 por cada 100.000 habitantes) y la mortalidad femenina un $58 \%$ (de 11,9 a 18,8 por cada 100.000 habitantes) y después empiezan a descender. by means of a differencing procedure: $\nabla x_{t}=x_{t}-x_{t-1}$ This means analyzing annual changes rather than raw data. The process of removing systematic variation within time series prior to the examination of potential causal relationships is referred to as "prewhitening". The residuals of a statistically adequate time series are distributed as a white noise process. A further step entails the inspection of the cross correlation function in order to estimate the association between the two prewhitened time series. This technique for undertaking time series analysis was suggested by Box and Jenkins and is often referred to as ARIMA (autoregressive integrated moving average) model (Box \& Jenkins, 1976). We used this model to estimate the relationship between the time series myocardial infarction mortality rate and level of beverage specific alcohol sale per capita in this paper.

\section{RESULTS}

The trends in total and sex-specific myocardial infarction mortality rates and vodka sale per capita are displayed in Figures 1-3. The graphical evidence suggests that the trends in both vodka sale per capita and myocardial infarction mortality for male and female seem to follow each other across the time-series. The two time series fluctuated over the period for both sexes: decreased in the first half of 1980, dramatically jumped from 1988 to 1993 (male mortality rate increased by 55.2\% (from 23.2 to 36 per 100.000 of residents), and female mortality rate increased by $58 \%$ (from 11.9 to 18.8 per 100.000 of residents), then began to decrease.

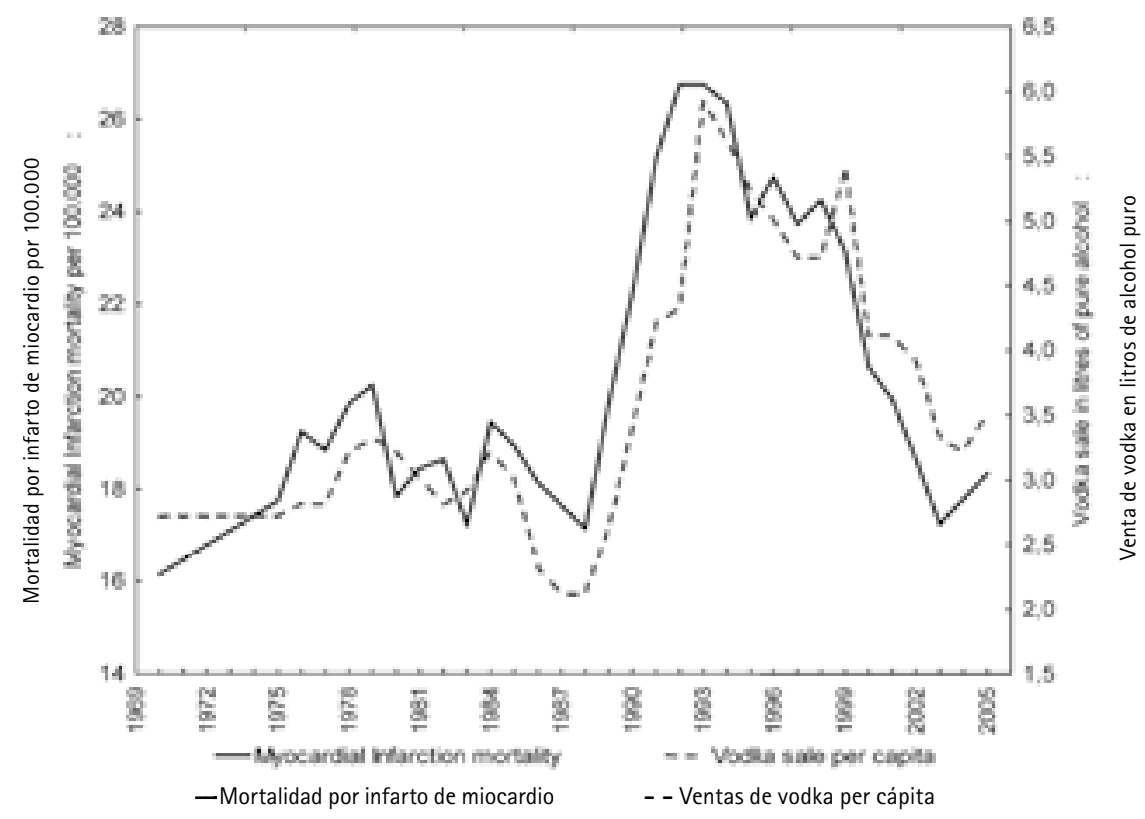

Figura 1. Tendencias en la venta de vodka per capita e índices de infarto de miocardio en Bielorrusia desde 1970 a 2005 Figure 1. Trends in vodka sale per capita and myocardial infarction mortality rate in Belarus from 1970 to 2005. 


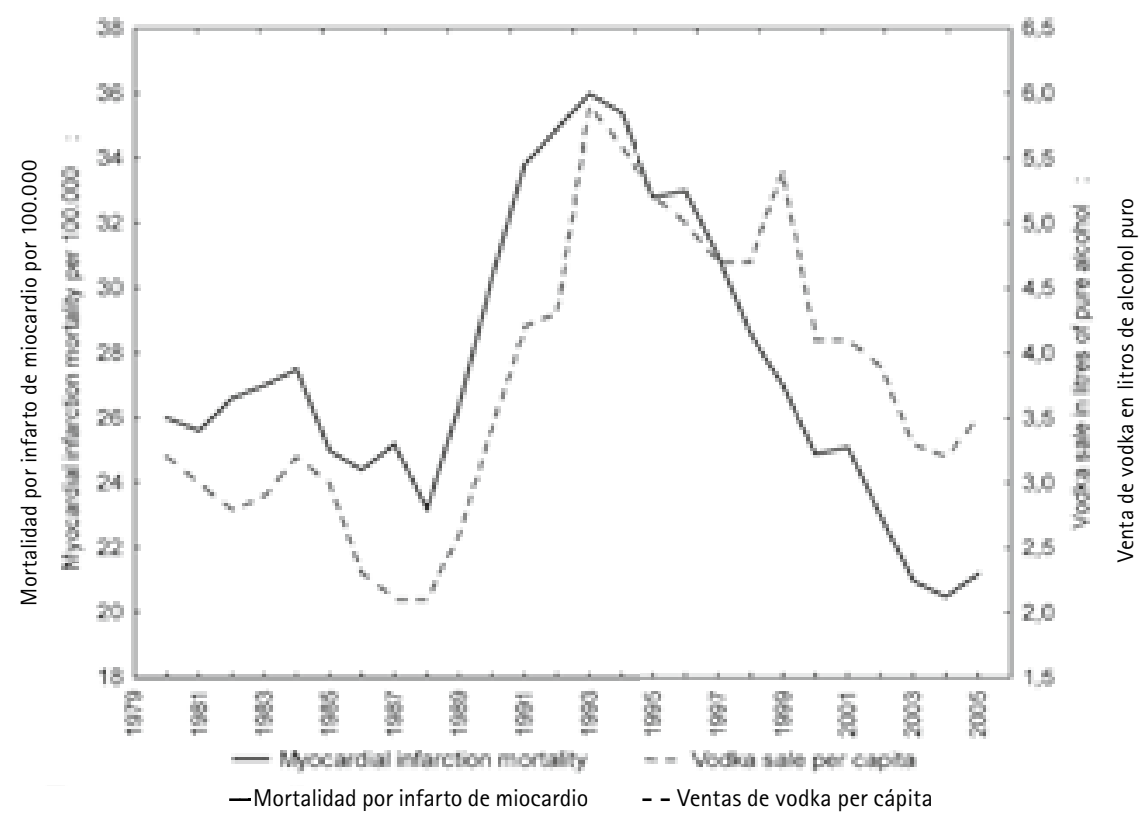

Figura 2. Tendencia en las ventas de vodka per cápita y la tasa de mortalidad masculina por infarto de miocardio en Bielorrusia desde 1970 hasta 2005.

Figure 2. Trends in vodka sale per capita and male myocardial infarction mortality rate in Belarus from 1970 to 2005.

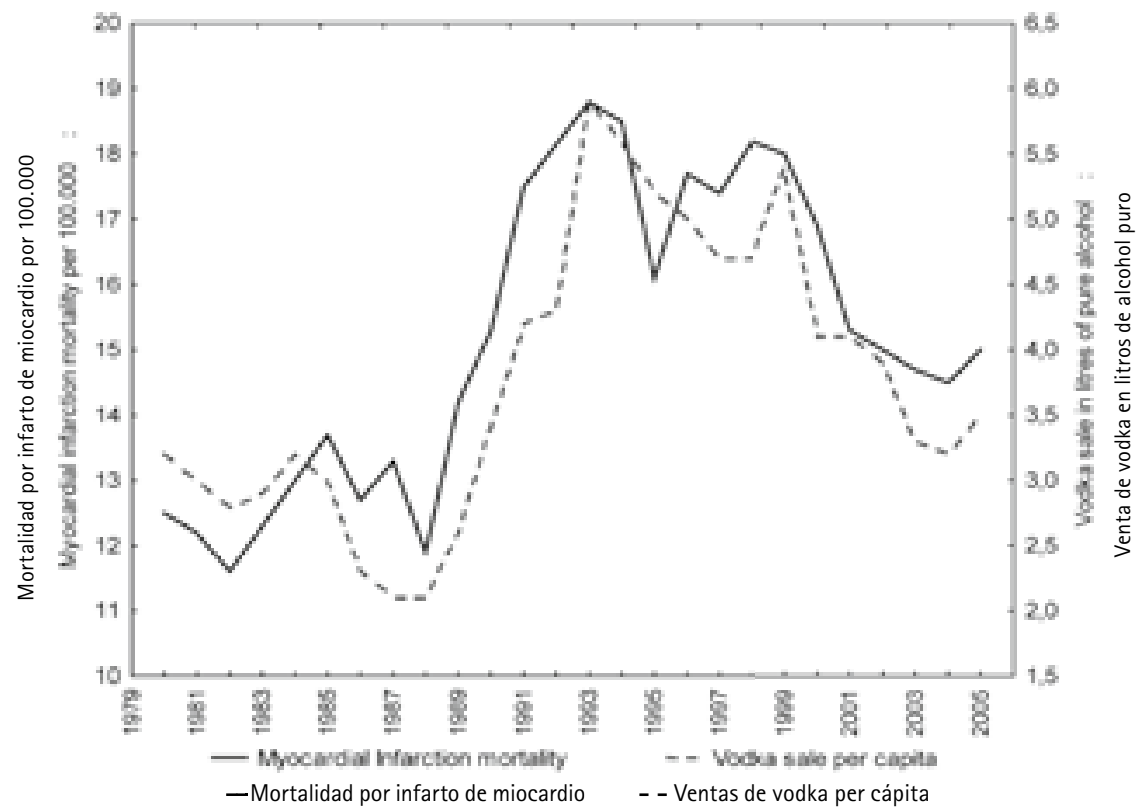

Figura 3. Tendencia en la venta de vodka per cápita y la tasa de mortalidad femenina por infarto de miocardio en Bielorrusia desde 1970 hasta 2005.

Figure 3. Trends in vodka sale per capita and female myocardial infarction mortality rate in Belarus from 1970 to 2005.

El análisis de correlaciones de Spearman sugiere una fuerte asociación positiva entre el nivel de venta de vodka per cápita y las tasas de mortalidad masculina y femenina (Tabla 1). El ratio de vodka por el total de venta de alcohol también es positivo en relación a la mortalidad por infarto de miocardio para ambos sexos. Al mismo tiempo, no hay correlación entre el total de venta de alcohol y la mortalidad por infarto de miocardio. Resulta interesante el hecho de que se
The Spearman's correlation analysis suggests the strong positive association between the level of vodka sale per capita and myocardial infarction mortality rate for male and female (table.1). The ratio of vodka to total alcohol sale is also positively related to myocardial infarction mortality for both sexes. At the same time, there is no correlation between the total level of alcohol sale and myocardial infarction mortality. Of interest may be fact that an inverse 
Tabla 1. Resultados del análisis de correlaciones. Efecto de la venta de alcohol/cigarrillos per cápita en la tasa de mortalidad por infarto de miocardio. Table 1. The results of correlation analysis. Effect of alcohol/cigarette sale per capita on myocardial infarction mortality rate.

\begin{tabular}{|l|c|c|c|c|c|c|c|c|c|c|}
\hline & \multicolumn{2}{|c|}{$\begin{array}{c}\text { Vodka } \\
\text { Vodka }\end{array}$} & \multicolumn{2}{c|}{$\begin{array}{c}\text { Vino } \\
\text { Wine }\end{array}$} & \multicolumn{2}{c|}{$\begin{array}{c}\text { Cerveza } \\
\text { Beer }\end{array}$} & \multicolumn{2}{c|}{$\begin{array}{c}\text { Total alcohol } \\
\text { Ratio vodka/total alcohol } \\
\text { Cigarette }\end{array}$} \\
\hline $\begin{array}{l}\text { IM (total) } \\
\text { MI (total) }\end{array}$ & 0,80 & 0,000 & $-0,06$ & 0,000 & $-0,46$ & 0,010 & $-0,27$ & 0,149 & 0,72 & 0,000 \\
\hline $\begin{array}{l}\text { IM (hombres) } \\
\text { MI (males) }\end{array}$ & 0,58 & 0,002 & $-0,58$ & 0,002 & $-0,03$ & 0,099 & $-0,25$ & 0,235 & 0,64 & 0,000 \\
\hline $\begin{array}{l}\text { IM (mujeres) } \\
\text { MI (females) }\end{array}$ & 0,92 & 0,000 & $-0,54$ & 0,007 & $-0,69$ & 0,000 & $-0,13$ & 0,258 & 0,283 \\
\hline
\end{tabular}

Tabla 2. Resultados del análisis de la correlación cruzada entre series temporales pre-blanqueadas. Efecto de la venta de alcohol/cigarrillos per cápita en la tasa de mortalidad por infarto de miocardio.

Table 2. The results of cross-correlation analysis between prewhitened time series. Effect of alcohol/cigarette sale per capita on myocardial infarction mortality rate.

\begin{tabular}{|l|c|c|c|c|c|c|}
\hline & \multicolumn{3}{|c|}{ Vodka } & \multicolumn{2}{c|}{ Ratio vodka/total alcohol } \\
\cline { 2 - 6 } & $\begin{array}{c}\text { Intervalo } \\
\text { Lag }\end{array}$ & $r$ & $\begin{array}{c}\text { Error estándar } \\
\text { Std Error }\end{array}$ & $\begin{array}{c}\text { Intervalo } \\
\text { Lag }\end{array}$ & $\begin{array}{c}\text { Error estándar } \\
\text { Std Error }\end{array}$ \\
\hline $\begin{array}{l}\text { IM (total) } \\
\text { MI (total) }\end{array}$ & 0 & 0,52 & 0,20 & 0 & 0,43 & 0,17 \\
\hline $\begin{array}{l}\text { IM (hombres) } \\
\text { MI (males) }\end{array}$ & 0 & 0,65 & 0,20 & 0 & 0,76 \\
\hline $\begin{array}{l}\text { IM (mujeres) } \\
\text { MI (females) }\end{array}$ & 0 & 0,62 & 0,20 & 0 & 0,40 & 0,20 \\
\hline
\end{tabular}

Tabla 3. Efectos estimados (modelo ARIMA bivariable) de la venta de vodka en la tasa de mortalidad por infarto de miocardio. Table 3. Estimated effects (bivariate ARIMA model) of vodka sale on myocardial infarction mortality rate.

\begin{tabular}{|l|c|c|c|}
\hline \multirow{2}{*}{} & \multicolumn{3}{|c|}{ Vodka } \\
\cline { 2 - 4 } & $\begin{array}{c}\text { Modelo } \\
\text { Model }\end{array}$ & $\begin{array}{c}\text { Estimado } \\
\text { Estimated }\end{array}$ & $\begin{array}{c}\mathrm{p} \\
\mathrm{p}\end{array}$ \\
\hline $\begin{array}{l}\text { IM (total) } \\
\text { MI (total) }\end{array}$ & $1,1,0$ & 0,072 & 0,000 \\
\hline $\begin{array}{l}\text { IM (hombres) } \\
\text { MI (males) }\end{array}$ & $1,1,0$ & 0,082 & 0,001 \\
\hline $\begin{array}{l}\text { IM (mujeres) } \\
\text { MI (females) }\end{array}$ & $1,1,0$ & 0,068 & 0,000 \\
\hline
\end{tabular}

encontró una relación inversa entre la tasa de mortalidad por infarto de miocardio y el nivel de venta de vino/cerveza per cápita. Como puede verse en la Figura 1, se da una tendencia de forma $\mathrm{S}$ en la tendencia de las series temporales. Esta tendencia se eliminó mediante un procedimiento de diferenciación de primer orden. Después del pre-blanqueado de las correlaciones cruzadas entre la venta de una bebida alcohólica especifica y la mortalidad por infarto de miocardio se inspeccionaron las series temporales. Los resultados indican una correlación estadística significativa entre la venta de vodka per cápita/el ratio del vodka en el total de la venta de alcohol y la mortalidad por infarto de miocardio para hombres y mujeres con un intervalo cero (Tabla 2). Al mismo tiempo, no hay correlación cruzada entre el nivel de ventas de vino/ cerveza y la mortalidad por infarto de miocardio. Por tanto, la correlación positiva entre estas variables era espuria. La especificación de un modelo ARIMA bivariable y los resultados de los análisis se presentan en la Tabla 3. Puede verse que, los efectos estimados de la venta de vodka en la mortalidad por infarto de miocardio son estadisticamente significantes para ambos sexos. El análisis sugiere que 1 litro per cápita de incremento en la venta de vodka tiene como resultado un aumento del $7,2 \%$ de la tasa de mortalidad por infarto de miocardio $(8,2 \%$ de aumento en la mortalidad masculina y $6,2 \%$ de aumento en la femenina). relation was found between myocardial infarction mortality rate and the level of wine/beer sale per capita. As can be seen from Figure 1, there is S-shape trend in the time series. This trend was removed by means of first-order differencing procedure. After pre-whitening the cross-correlations between beverage-specific alcohol sale and myocardial infarction mortality time series were inspected. The outcome indicated statistically significant cross-correlation between vodka sale per capita/the ratio of vodka to total alcohol sale and myocardial infarction mortality for male and female at zero lag (table. 2). At the same time, there is no cross-correlation between the level of wine/beer sale and myocardial infarction mortality. So, positive correlation between these variables was spurious. The specification of the bivariate ARIMA model and outcome of the analyses are presented in Table 3. It can be seen, that the estimated effects of vodka sale on myocardial infarction mortality are clearly statistically significant for both sexes. The analysis suggests that a 1 litre increase in vodka sale per capita would result in a $7.2 \%$ increase in myocardial infarction mortality rate $(8.2 \%$ increase in male mortality and $6.8 \%$ increase in female mortality). 


\section{DISCUSIÓN}

Como puede verse, la mortalidad por infarto de miocardio y la tendencia en ventas de vodka se correlacionan más o menos con las grandes transformaciones sociales. A principios de 1980, el reciente nuevo líder soviético Andropov tomó medidas destinadas a la reducir la disponibilidad de alcohol. Se hizo en el marco de una campaña para reforzar la disciplina en el trabajo y tuvo como efecto una bajada en la venta de vodka y en los infartos de miocardio. Los descensos sustanciales en las dos series temporales a mediados de la década de 1980 se corresponden con las campañas antialcohol de Gorbachov, que redujeron significativamente el consumo de alcohol limitando su fabricación y disponibilidad. Los dramáticos aumentos en dos tendencias temporales a principios de la década de 1990 se corresponden con la disolución de la Unión Soviética y los profundos cambios socio-económicos y políticos acaecidos durante el periodo transicional hacia el post-comunismo. También parece plausible, que las ventas de vodka y las tasas de mortalidad por infarto de miocardio observadas a principios de 1990 fueran resultado de la crisis socio-económica y que las condiciones anómicas se vieran reforzadas con la abolición del monopolio estatal del alcohol en 1992 y un aumento en la disponibilidad de alcohol (Razvodovsky, 2008).

El análisis de las series temporales sugiere una relación positiva entre las ventas de vodka per cápita y la mortalidad por infarto de miocardio cuando el intervalo es cero. De hecho, la asociación contemporánea entre las dos variables apoyaría la cuestión de que el "binge drinking" constituye un factor de riesgo para la mortalidad por infarto de miocardio a nivel agregado. Es importante señalar que el tamaño de la asociación bivariable entre ventas de vodka y mortalidad por infarto de miocardio entre los hombres es sustancialmente mayor que para las mujeres. En principio, esto no resulta sorprendente ya que el "binge drinking" de vodka se encuentra firmemente enraizado como parte de la cultura de alcohol masculina (Razvodovsky, 2003).

En este punto deberíamos señalar que severas limitaciones en este estudio pueden haber afectado sus resultados. Podría darse el caso de que dos tendencias temporales se vieran afectadas por una variable que se prestara a confusión como, por ejemplo, que la correlación fuera casual. Algunos investigadores han argumentado que la angustia psicosocial, resultado de los dramáticos cambios sociales, económicos y políticos ocurridos, fueron el determinante de los bruscos aumentos tanto en el consumo de alcohol como en la tasa de mortalidad cardiovascular en las repúblicas eslavas de la antigua Unión Soviética a principios de la década de 1990 (Gavrilova, Semyonova, Evdokushkina y Gavrilov, 2000; Stone, 2000). Esto significa que la angustia puede precipitar el "binge drinking" como un mecanismo para sobrellevarla contribuyendo así al aumento en la tasa de mortalidad cardiovascular. La influencia de la angustia psicosocial en la mortalidad cardiovascular resulta convincente (Marmot, 1988). Varios estudios retrospectivos arguyen que existe una relación entre situaciones seriamente estresantes (desastres naturales, atentados terroristas) o acontecimien-

\section{DISCUSSION}

As can be seen, the myocardial infarction mortality and vodka sale trends have been more or less correlated with the great social transformation. At the beginning of 1980s the newly coming Soviet state leader Andropov took a number of measures aimed at alcohol availability restriction. It was done in the framework of the labor discipline strengthening campaign and resulted in a decline in the vodka sale and myocardial infarction mortality rates. The substantial decrease in the two time series in the mid-1980s corresponds with the anti-alcohol campaigns by Gorbachev, which significantly reduced alcohol consumption by limiting its manufacture and availability. The dramatic increases in the two time trends in the early 1990s corresponds to dissolution of the Soviet Union and the profound socio-economic and political changes occurring during the transitional period to the post communism. It also seems plausible, that vodka sale and myocardial infarction mortality rates increase observed in the yearly 1990s resulted from the socio-economic crisis and anomic conditions was reinforced by the abolishing the state alcohol monopoly in 1992 and substantial increase in alcohol availability (Razvodovsky, 2008).

The time series analysis suggests a positive relationship between vodka sale per capita and myocardial infarction mortality when there is zero lag. In fact, the contemporaneous association between the two variables may support the point that binge drinking is a risk factor for myocardial infarction mortality at the aggregate level. It is important to point out that the size of the bivariate association between vodka sale and myocardial infarction mortality for men is substantially greater than for women. In principle, this is not surprisingly, because binge drinking of vodka is a deeply rooted part of male drinking culture (Razvodovsky, 2003).

At this stage we should to point out several limitations of the study that may have affected the outcome. It might be the case that the two time trends are being influenced by a confounder variable i.e. that the correlation is spurious. Several scholars have argue that the psychosocial distress resulting from the dramatic social, economic and political changes that have occurred was the main determinant of the sharp increases in both alcohol consumption and cardiovascular mortality rate in the former Soviet Slavic republics in the early 1990s (Gavrilova, Semyonova, Evdokushkina \& Gavrilov, 2000; Stone, 2000). This means that distress may precipitate binge drinking as a coping mechanism and thus contribute to grow in cardiovascular mortality rate. The influence of psychosocial distress on cardiovascular mortality is convincing (Marmot, 1988). Several retrospective studies claim to show a relationship between acute life stressors (natural disasters, terrorist attacks) and chronic stressful life events (job strain, lack of social support) and subsequent precipitation of acute myocardial infarction (Bhatia, Tiwari \& Balkrishna, 1990; Geenwood, Muir, Packham \& Madeley, 1996; Kivimaki, Leino-Arjas, Luukkonen, Riihimaki, Vahtera \& Kirjonen, 
tos estresantes crónicos (presión del trabajo, falta de apoyo social) y un consecuente aumento del infarto de miocardio grave (Bathia, Tiwari y Balkrishna, 1990; Greenwood, Muir, Packham y Madeley, 1996; Kivimaki, Leino-Arjas, Luukkonen, Riihimaki, Vahtera y Kirjonen, 2002). Se ha mostrado que la recesión económica, medida por la tasa de desempleo, se relaciona con un aumento en la tasa de mortalidad por enfermedad coronaria (Brenner, 1987). Los estudios clínicos sugieren que la angustia constituye un factor de riesgo significante en la muerte de pacientes con enfermedades coronarias (Stansfeld, Fuhrer, Shipley y Marmot, 2002). Hay diversos mecanismos potenciales para el efecto de la angustia en la mortalidad cardiovascular. La angustia psicosocial puede causar de forma directa anormalidades psicopatológicas como la activación del pituitario-hipotalámico, la hiperactividad adrenérgica, el incremento de coágulos de plaquetas, una elevación del nivel fibrinógeno, y una progresión acelerada de la arteriosclerosis cardiaca (Hiroyasu, Chigusa, Yamamoto, Toyoshima, Tanabe y Kikuchi, 2002). La angustia psicosocial puede asociarse directamente con la mortalidad cardiovascular a través de estilos de vida poco saludables tales como el "binge drinking" y el tabaco. Por tanto, la angustia psicosocial puede constituir un importante factor subyacente en las fluctuaciones de mortalidad por infarto de miocardio en Bielorrusia durante las últimas décadas. Es posible, sin embargo, que tanto la angustia psicosocial como las relaciones del alcohol con la mortalidad por infarto de miocardio a nivel agregado sean falsas y que haya otros factores de riesgo importantes como, por ejemplo, el fumar. El tabaco se ha estimado constituye el factor de riesgo más peligroso con respecto a la mortalidad cardiovascular y también se ha correlacionado con el consumo de alcohol (Semenciw et al., 1988). Parece haber casi una relación de respuesta-dosis entre el consumo de cigarrillos y la mortalidad cardiovascular (Ockene y Miller, 1997). Debería tenerse presente, sin embargo, que las relaciones entre consumo de cigarrillos y muerte por enfermedad coronaria se distribuyen a lo largo de 0-15 años (Semenciw et al., 1988). En general, los resultados de análisis de series temporales sugieren que el consumo de cigarrillos no constituye un factor suficientemente explicativo para las fluctuaciones significativas en la tasa de mortalidad por infarto de miocardio en Bielorrusia entre 1980 y 1990. De tal forma que, en vez de jugar un papel causal, fumar puede constituir un factor de confusión.

En conclusión, los resultados presentados en este estudio sugieren una relación positiva entre las ventas de vodka y la tasa de mortalidad por infarto de miocardio a nivel agregado y apoyan la hipótesis de que el "binge drinking" de alcoholes fuertes constituye un factor de riesgo del infarto de miocardio a nivel individual. Por consiguiente, desde un punto de vista de políticas públicas, los resultados de este estudio sugieren también que los programas de prevención de la mortalidad relacionada con problemas cardiovasculares deberían centrarse más en tratar la estructura del consumo de alcohol.
2002). It was shown, that economic recession as measured by the unemployment rate is related to increase in the heart disease mortality rate (Brenner, 1987). The clinical studies suggest that psychosocial distress is a significant risk factor for death in patients with coronary heart disease (Stansfeld, Fuhrer, Shipley \& Marmot, 2002). There are several potential mechanisms for the effect of psychosocial distress on cardiovascular mortality. Psychosocial distress may cause direct pathophysiological abnormality including hypothalamic pituitary axis activation, adrenergic hyperactivity, increased platelet aggregation, raised fibrinogen level, and accelerated progression of cardiac atherosclerosis (Hiroyasu, Chigusa, Yamamoto, Toyoshima, Tanabe \& Kikuchi, 2002). Psychosocial distress may be indirectly associated with cardiovascular mortality through unhealthy lifestyle such as binge drinking and smoking. So, psychosocial distress may be an important underlying factor in myocardial infarction mortality fluctuation in Belarus during the last decades. It is, however, possible that both the psychosocial distress and alcohol relations to myocardial infarction mortality at the aggregate level are spurious and there is other powerful risk factor, i. $m$. smoking. Tobacco has been estimated to be the most harmful risk factor with regard to the cardiovascular mortality and also be correlated with alcohol consumption (Semenciw, et al., 1988). There seems to be almost a doseresponse relationship between cigarette consumption and cardiovascular mortality (Ockene \& Miller, 1997). It should be kept in mind, however, that relations of cigarette consumption to heart disease mortality are distributed over at least 0-15 years (Semenciw, et al., 1988). In general, the results of time series analysis suggest that cigarette consumption is not a sufficient explanatory factor for the significant fluctuation in myocardial infarction mortality rate in Belarus in the 1980s and 1990s. Thus, rather that playing the major causal role, smoking may represent a confounding factor.

In conclusion, the results of present study suggest a positive relation between vodka sale and myocardial infarction mortality rate at aggregate level and support the hypothesis that binge drinking of strong spirits is a risk factor of myocardial infarction at the individual level. Thus, from a public policy point of view, the outcome of this study also suggests that cardiovascular-related mortality prevention programs should put more focus on addressing alcohol consumption structure. 


\section{REFERENCIAS / REFERENCES}

Anderson, P. (2005). Alcohol and coronary heart disease. Adicciones, 17: $3-10$

Bhatia, M. S., Tiwari, A. y Balkrishna, G. H. (1990). Type A behaviour, life events and myocardial infarction: An inpatient study in Sweden. Journal of Psychosomatic Research, 92: 95-100.

Box, G.E.P. y Jenkins G.M. (1976). Time Series Analysis: forecasting and control. London: Holden-Day Inc.

Brenner, M.H. (1987). Economic change, alcohol consumption and heart disease mortality in nine industrialized countries. Social Science \& Medicine, 25: 119-132.

Britton, A. y McKee, M. (2000). The relation between alcohol and cardiovascular disease in Eastern Europe. Explaining the paradox. Journal of Epidemiology \& Community Health, 54: 328-332.

Chenet, L., McKee, M., Leon, D., Shkolnikov, V. y Vassin, S. (2001). Alcohol and cardiovascular mortality in Moscow: new evidence of a causal association. Journal of Epidemiolology and Community Health, 52: 772-74.

Corrao, G., Rubbiati, L., Bagnardi, V., Zambon, A. y Poikolainen, K. (2000). Alcohol and coronary heart disease: a meta-analysis. Addiction, 95: 1505-23.

Gavrilova, N.S., Semyonova, V.G., Evdokushkina, G.N. y Gavrilov, L.A. (2000). The response of violent mortality to economic crisis in Russia. Population Research and Policy Review, 19: 397-419.

Greenwood, D.C., Muir, K.R., Packham C.J. y Madeley, R.J. (1996). Coronary heart disease: a review of the role of psychosocial stress and social support. Journal of Public Health Medicine, 18: 221-231.

Hemstrom, 0. (2001). Per capita alcohol consumption and ischemic heart disease mortality. Addiction, 96: 93-112.

Hiroyasu, I., Chigusa, D., Yamamoto, A., Toyoshima, H., Tanabe, N. y Kikuchi, S. (2002). Perceived mental stress and mortality from cardiovascular disease among Japanese men and women. Circulation, 106: 1229-1234.

Kauhanen, J., Kaplan, G.A., Goldberg, D.E. y Salonen, J.T. (1997). Beer binging and mortality - results from the Kuopio ischemic heart disease risk factor study, a prospective population based study. British Medical Journal, 315: 846-851.

Kivimaki, M., Leino-Arjas, P., Luukkonen, R., Riihimaki, H., Vahtera, J. y Kirjonen, J. (2002). Work stress and risk of cardiovascular mortality: prospective cohort study of industrial employees. British Medical Journal, 325: 857-864.

Klatsky, A.L., Armstrong, M.A. y Friedman, G.D. (1997). Red wine, white wine, liquor, beer, and risk for coronary artery disease hospitalization. American Journal of Cardiology, 80: 416-20.

Kuulasmaa, K., Tunstall-Pedoe, H., Dobson, A., Fortmann, S., Sans, S., Tolonen, H., Evans, A., Ferrario, M. y Tuomilehto, J. (2000). Estimation of contribution of changes in classic risk factors to trends in coronary-event rates across the WHO MONICA Project populations. Lancet, 355: 675-87.

Marmot, M. G. (1988). Psychosocial factors and cardiovascular disease: epidemiological approaches. European Heart Journal, 6: 690-697.
Marmot, M.G. (2001). Commentary: reflection on alcohol and coronary heart disease. International Journal of Epidemiology, 30: 729-34.

McElduff, P. y Dobson, A.J. (1997). How much alcohol and how often? Population based case-control study of alcohol consumption and risk of major coronary events. British Medical Journal, 314: 1159-1164.

Mucamal, K.J., Conigrave, K.M., Mittleman, M.A., Camargo, C.A.Jr., Stampfer, M.J., Willet, W.C. y Rimm, E.B. (2003). Roles of drinking pattern and type of alcoholic consumed in coronary heart disease in men. New England Journal of Medicine, 348: 109-118.

Nemtsov, A.V. (2002). Alcohol-related human losses in Russia in the 1980s and 1990s. Addiction, 97: 1413-1425.

Norstrom, T. y Skog, O.J. (2001). Alcohol and mortality: methodological and analytical issue in aggregate analysis. Addiction, 96: 5-17.

Ockene, I.S. y Miller, N.H. (1997). Cigarette Smoking, Cardiovascular Disease and Stroke. Circulation, 96: 3243-3247.

Pares, A. \& Caballeria, J. (2002). Patología orgánica. Adicciones, 14 (Suppl.1): 155-173.

Puddey, I.B., Rakic, V., Dimmitt, S.B. y Beilin, L.J. (1999). Influence of pattern of drinking on cardiovascular disease and cardiovascular risk factors - a review. Addiction, 94: 649-663.

Razvodovsky, Y.E. (2001). Alcohol and cardiovascular mortality: epidemiological aspect. Alcologia, 13: 107-113.

Razvodovsky, Y.E. (2003). Alcohol and mortality crisis in Belarus. Grodno: Medical University Press.

Razvodovsky, Y.E. (2005). Aggregate level time series association between alcohol consumption and cardiovascular mortality. Adicciones, 17: 43-60.

Razvodovsky, Y.E. (2008). Alcohol psychoses and all-cause mortality in Belarus. Adicciones, 20: 395-405.

Room R., Babor, T., Rehm, J. (2005). Alcohol and public health. Lancet 365: 519-530.

Rossinen, J., Partanen J., Koskinen P., Toivonen, L., Kupari, M. y Nieminen, M.S. (1996): Acute heavy alcohol intake increases silent myocardial ischemia in patients with stable angina pectoris. Heart, 75: 563-567.

Semenciw, R.M., Morrison, H.I., Mao, Y., Johansen, H., Davies, J. y Wigle, D.T. (1988). Major risk factors for cardiovascular disease mortality in adults: results from the Nutrition Canada Survey cohort. International Journal of Epidemiology, 17: 317-324.

Shaper, A.G., Phillips, A.N., Pocock, S.J. y Walker, M. (1987). Alcohol and ischaemic heart disease in middle aged British men. British Medical Journal, 294: 733-737.

Shaper, A.G. y Wannamethee, S.G. (2000). Alcohol intake and mortality in middle aged men with diagnosed coronary heart disease. Heart, 83: 394-399.

Stansfeld, S.A., Fuhrer, R., Shipley, M.J. y Marmot, M.G. (2002). Psychosocial distress as a risk factor for coronary heart disease in the Whitehall II Study. International Journal of Epidemiology, 31: $248-255$.

Stone, R. (2000). Stress: The invisible hand in Eastern Europe's death rates. Science, 288: 1732-1733

Turnet, Ch. \& Anderson, P. (1990). Alcohol and cardiovascular disease: what is the relationship? Addiction, 85: 851-853. 
